\title{
WHY MARKET FREEDOMS ARE NO FUNDAMENTAL RIGHTS: \\ A COMPETENCE APPROACH
}

\begin{abstract}
Stephan Gregor*
Summary: Market freedoms resemble in many aspects fundamental rights. Since individuals can invoke them against the measures of Member States, they are subjective rights which restrict the competence of the Member States in favour of the individual. Besides this most apparent function, market freedoms are also about the distribution of competence among Member States, and between Member States and the European Union. Market freedoms appear to confer the right to market access in the remaining area of their application. Thus, market freedoms seem to reserve an area of protection to the individual, which is necessary for them to be deemed fundamental rights. This area, however, is only reserved in relation to the Member States. According to the incompetence approach which is presented here, European institutions are bound by market freedoms only in an indirect way. It is just due to a lack of competence that a conflict between market freedoms and measures of European institutions seldom conflict. Since market freedoms do not strive for comprehensive protection in relation to any bearer of state authority, they lack the decisive feature of fundamental rights.
\end{abstract}

\section{Introduction}

Hobbes construed the state as an almighty Leviathan. Hobbes's state is competent for everything. The liberal contribution to this simple state model is human rights. ${ }^{1}$ Human rights reserve a certain area for the competence of each and every individual. Not the Leviathan, but the individual is competent to decide whom to marry (art 23 ICCPR), ${ }^{2}$ where to settle (art 12 ICCPR), what to regard as the truth, or which god to worship (art 18 ICCPR). Human rights tell us about the distribution of competence between the individual on the one hand and state authority on the other. Human rights are silent with regard to the distribution of competence within state authority. No additional player will appear if we

\footnotetext{
* Researcher and PhD candidate, Faculty of Law, FernUniversität in Hagen.

1 Ernst-Ulrich Petersmann, 'National Constitutions, Foreign Trade Policy and European Community Law' (1992) 3 (1) EJIL 7.

2 International Covenant on Civil and Political Rights (adopted 16 December 1966, entered into force 23 March 1976) 999 UNTS 171 and 1057 UNTS 407 (ICCPR).
} 
distinguish between different bearers of state authority. A third player will not appear if a supranational organisation like the European Union joins the game. It does not matter what level of state authority is about to intrude into the area of competence reserved for the individual. Human or fundamental rights address state authority at any level. Human rights prohibit, for instance, torture (art 7 ICCPR), no matter if it is applied at the local, regional or national level (art 50 ICCPR). And states are indubitably not allowed to do away with the prohibition of torture just by founding a supranational bearer of state authority as is the case with the European Union. Thus, supranational organisations are part of state authority, and not a third party.

When it comes to market freedoms, there are more players than just state authority and the individual. Without doubt, the European Union is one of these actors. In the application of the free movement of goods, for example, one must distinguish between the country of origin and the country of destination. So, among state authority, there are at least three actors. Unlike fundamental rights, market freedoms differentiate between the bearers of state authority. It will be shown that the free movement of goods, for instance, is to a significant extent nothing more than a rule on distributing competence among the Member States. And it is doubtful if the remainder that can be assigned as competence to the individual deserves to be called fundamental rights.

Market freedoms can be interpreted as fundamental or human rights within the constitutional framework of the economic constitution of the European Union, ie the Treaty on the Functioning of the European Union (TFEU). The Court repeatedly suggested such a legal nature, especially of the free movement of persons in its case law. The Court spoke of art 45 TFEU as granting the fundamental right of persons to move freely within the [Union]' in the El-Yassini case. ${ }^{3}$ Or it stated that access to employment is 'a fundamental right' conferred individually on each worker by this article. ${ }^{4}$

The Court even went beyond this terminological proximity in the $R u$ tili judgment by comparing the limitations to free movement under art 45 TFEU with those to freedoms under the European Convention on Human Rights with regard to proportionality and the intangibility of the essence of a protected right. ${ }^{5}$

Admittedly, market freedoms resemble in many respects fundamental rights. ${ }^{6}$ Since individuals can invoke them against the measures of

Case C-416/96 El-Yassini [1999] ECR I-1209 para 45.

4 Case 222/86 Unectef $v$ Heylens [1987] ECR 4097, para 14.

5 Case 36/75 Rutili v. Ministre de l'intérieur [1975] ECR 1219, para 32.

6 Thorsten Kingreen in Christian Calliess and Matthias Ruffert, EUV/EGV, Das Verfassungsrecht der Europäischen Union mit Europäischer Grundrechtecharta $\left(3^{\text {rd }}\right.$ edn Verlag $\mathrm{CH}$ Beck, Munich 2007), art 28-30 EC, recitals 66-68. 
Member States, they are subjective rights which restrict the competence of the Member States in favour of the individual. Besides this frequent function, when market freedoms are dealt with, market freedoms rather concern the distribution of competence among Member States, and between Member States and the European Union.

The competence conceded to the individual is not necessarily an exclusive competence. Most human rights have limitations, ie the state may intrude into the area of protection if this is justified. In the language of competence, competence is shared between state authority and the individual, whereupon the delineation is carried out by means of admissible justification $^{7}$ and the principle of proportionality. Individuals are, for instance, competent to decide what to write in a children's book. The State, however, may interfere in the individual's choice for the protection of minors, but only if this obeys the principle of proportionality (cf art 10 ECHR). ${ }^{8}$ We will see that to a significant extent market freedoms do not even offer an area of protection, and so we do not arrive at justification and proportionality (section 2).

Market freedoms appear to confer a right to market access in the remaining area of application. In this way, market freedoms seem to reserve an area of protection for the individual, which is necessary for them to be deemed fundamental rights. This area, however, is only reserved in relation to Member States. The European institutions are bound by the market freedoms only in an indirect way. It is just due to the lack of competence that market freedoms and the measures of European institutions seldom conflict (section 3 ).

\section{Distribution of competence within state authority}

The free movement of goods has always been the pioneer market freedom for the development of case law and doctrine. The free movement of goods comprises a customs union (art 30 TFEU) and a prohibition of quantitative trade restrictions, including measures having equivalent effect (art 34-37 TFEU). The customs union mostly goes unnoticed when it comes to the free movement of goods. The same is true for quantitative restrictions. Customs duties and quantitative restrictions are effectively abolished within the internal market. Therefore, the discussion focuses on measures having an effect equivalent to quantitative restrictions, and there particularly on restrictions on imports. The ECJ has recently clarified how to scrutinise measures having an effect equivalent to the qu-

\footnotetext{
7 Joseph Raz, 'Human Rights Without Foundations' (March 2007) University of Oxford Faculty of Law Legal Studies Research Paper Series, Working Paper No 14/2007 9.

$8 \quad$ Handyside $v$ United Kingdom (App no 5493/72) ECHR 1976.
} 
antitative restriction on imports in some preliminary observations on the two-wheeler trailer decision. ${ }^{9}$

\subsection{Dassonville}

According to the Dassonville formulation, which was coined in the eponymous judgment, ${ }^{10}$ 'all trading rules enacted by Member States which are capable of hindering, directly or indirectly, actually or potentially, intra-[European] trade are to be considered as measures having an effect equivalent to quantitative restrictions'. ${ }^{11}$ For that reason, they are prohibited under art 35 TFEU. ${ }^{12}$ This definition covers two prohibitions: a prohibition on discrimination and one on restriction. Prohibition on discrimination means that Member States must not treat imported products less favourably than domestic ones. ${ }^{13}$ The prohibition on restriction addresses measures which hinder the access of products originating in other Member States to the market of a Member State without being discriminatory. ${ }^{14}$ The most important group within these measures can be encapsulated by the key term 'dual regulatory burden'.

\subsection{Cassis de Dijon}

These measures hamper intra-European trade because of the related diverging legal and technical requirements within the internal market. ${ }^{15}$ Legal approximation can relieve producers who want to export their products to another Member State of the dual regulatory burden. If there is no harmonisation, the restriction test can serve the same purpose. The Member State where an imported product is to be sold may only impose such restrictions on goods lawfully manufactured in another Member State which are necessary to fulfil mandatory requirements. ${ }^{16}$ This is the key finding of the Cassis de Dijon judgment ${ }^{17}$ which is certainly one of the most influential ECJ decisions. ${ }^{18}$

Case C-110/05 Commission v Italy [2009] ECR I-519, paras 33-7.

10 Case 8/74 Dassonville [1974] ECR 837.

11 Dassonville (n 10) para 5.

12 Commission $v$ Italy (n 9) para 33.

13 Commission $v$ Italy (n 9) para 37.

14 Tamara Perišin, 'Sloboda kretanja roba i njezine implikacije naregulatornu autonomiju u Republici Hrvatskoj' (2007) 44 Politička misao, 17, 21.

15 Perišin (n 14) 24.

16 Commission v Italy (n 9) para 35.

17 Case 120/78 Rewe v Bundesmonopolverwaltung für Branntwein [1979] ECR 649.

18 Derrick Wyatt, 'Trade, Tax and Takeovers: Can the European Court De-Regulate Europe Despite Resistance From the Council and Parliament?' (2005) 1 Croatian Yearbook of European Law and Policy 95, 95. 
The ECJ established the restriction test in this milestone decision. ${ }^{19}$ A German supermarket chain was not allowed to sell French Cassis de Dijon liqueur in Germany because the blackcurrant liqueur contained less alcohol than prescribed by German law in order to be marketed as liqueur. The Court held that the free movement of goods only allows national legislation to impose restrictions on goods lawfully produced in another Member States that are necessary to fulfil mandatory requirements. The Cassis de Dijon judgment can be misunderstood as granting something like a right to deregulation or liberty from unnecessary regulation.

Actually, the Cassis de Dijon judgment is about the distribution of competence in the first place. It contributes to the broader idea that within the internal market it is sufficient if a product complies with one set of rules, and in the case of Cassis de Dijon, with the rule of the country of origin. The judgment did not say that product-related regulation needs to be justified. In fact, the rules on minimum alcoholic strength of the country of origin (France) were not questioned at all. The Cassis de Dijon judgment is only about additional rules imposed by the country of destination. Such rules are not prohibited, but they must prove to be necessary.

These additional rules may constitute obstacles and require justification. In principle, it is enough that goods comply with the rules of the country of origin. The country of destination may even impose additional restrictions if it is justified by the written grounds of justification in art 36 TFEU or if they are necessary in order to fulfil the mandatory requirements in the public interest. These additional restrictions are meant when the court rules that:

obstacles to the free movement of goods which are the consequence of applying, to goods coming from other Member States where they are lawfully manufactured and marketed, rules that lay down requirements to be met by such goods constitute measures of equivalent effect to quantitative restrictions even if those rules apply to all products alike. ${ }^{20}$

Products only enjoy the principle of mutual recognition if they are 'lawfully manufactured and marketed'. ${ }^{21}$ However, if the product does not comply with the rules that are in force in its country of origin, the country of destination is competent to set the product requirements. These rules cannot be tested if they are justified and necessary under the Cassis de Dijon doctrine. Products must comply with one set of rules. If they do not

19 Case 120/78 Rewe-Zentral AGv Bundesmonopolverwaltung für Branntwein [1979] ECR 649.

20 Commission v Italy (n 9) para 35.

${ }_{21}$ Commission v Italy (n 9) para 35. 
comply with those of the country of origin, they must obey the law at the point of sale whether it is 'necessary' or not.

Besides the restriction test, the discrimination test also serves the principle that it is enough if a product complies with one set of rules. The discrimination test ensures that the Member State competent for regulating the respective product does not impose additional rules in comparison with a product which is not part of intra-European trade. The country of origin may impose more severe restrictions on products intended for exportation only if this is justified under art 36 TFEU. So, in principle, a product needs only comply with the rules of the country of origin, and the discrimination test sees to it that the rules of the country of origin are the same as the rules that apply to goods for the domestic market. Only additional rules are 'obstacles' which call for justification.

\subsection{Reverse discrimination}

One rather odd feature of the restriction test of the free movement of goods is that the Member States may apparently discriminate against their own nationals. ${ }^{22}$ Usually, it is the other way round: some fundamental rights are restricted to the citizens of the respective state. They could be called citizens' rights or civil rights in contrast to human rights which strive for universal application. The right to asylum is a counterexample of a human right restricted to non-citizens.

While foreign producers can choose if they want to comply with the rules of the country of production or with those of the country of sale, domestic producers have no choice. They must obey their domestic law no matter how unnecessary it may seem and how disadvantageous it is for their competitiveness in comparison with imported goods.

Reverse discrimination is a clear consequence of the rule governing the distribution of competence between different bearers of state authority: it is enough if you comply with one set of rules, either that of the country of production or that of the country of sale. Since both are one and the same, producers intending to sell their product on the domestic market have no choice. They must conform to domestic law.

\section{$2.4 \mathrm{Keck}$}

The very broad field of application of the Cassis de Dijon doctrine is limited by the $K e c k^{23}$ judgment. ${ }^{24}$ In accordance with this jurisdiction, certain selling arrangements are excluded from the prohibition of restric-

\footnotetext{
22 Claus Dieter Classen in Thomas Oppermann, Claus Dieter Classen \& Martin Nettesheim, Europarecht ( $4^{\text {th }}$ edn Verlag CH Beck, Munich 2009) § 23, recital 16.

23 Case C-267/91 Keck and Mithouard [1993] ECR I-6097.

24 Perišin (n 14) 24.
} 
tion (they may still be scrutinised under the discrimination test). Examples of certain selling arrangements are the prohibition to open shops on Sundays, ${ }^{25}$ the sale of certain goods to be reserved for licensed retailers, ${ }^{26}$ the availability of baby milk only at chemist shops ${ }^{27}$ and the requirement to observe a minimum profit margin for $\operatorname{sales}^{28}$.

With regard to certain selling arrangements, there is no principle of mutual recognition. It is not enough that a product complies with the selling arrangements of the country of origin; the rules on the destination market must be obeyed even if they are stricter than those on the market of origin. French liqueur, for instance, must not be sold in Germany on Sundays, because of Germany's laws on trading hours that 'observe the Sabbath', ${ }^{29}$ (art 40 Basic Law in connection with art 139 Weimar Constitution), although French shops may open on Sundays. Nevertheless, the idea that it is sufficient to comply with one set of rules is upheld. What is particular for selling arrangements is that there is no choice about which rules to obey. The selling of goods may be exclusively regulated by the Member State where they are sold. In the language of the competence approach, the competence for selling arrangements is attributed to the country of destination-first of all for practical reasons. A distribution of competence for regulation in accordance with the principle of mutual recognition would be unfeasible when it comes to selling arrangements. Just imagine German stores selling French liqueur on Sundays while all domestic goods cannot be sold.

If the country of sale has exclusive competence for certain selling arrangements, it follows as a matter of pure counterbalancing that the country of production must have exclusive competence for certain 'production arrangements' on the same footing. ${ }^{30}$ There are, indeed, rules regarding the production conditions where it would be impractical if they depended on the market for which the product is produced. Labour con-

\footnotetext{
25 Case C-69/93 Punto Casa and PPV [1994] ECR I-2355, para 12; Case C-418/93 Semeraro Casa Uno and others $v$ Sindaco del Comune di Erbusco and others [1996] ECR I-2975, para 12; trading hours of filling stations: Case C-401/92 Criminal proceedings against Tankstation 't Heukske and Boermans [1994] ECR I-2199, para 12; earlier judgments on Sunday selling without recourse to certain selling arrangements: Case 145/88 Torfaen Borough Council $v B \& Q$ PLC [1989] ECR 3851, para 14; Case C-169/91 Council of the City of Stoke-on-Trent and Norwich City Council v B \& Q Plc [1992] ECR I-6635, para 12.

26 Case C-387/93 Pretore di Genova v Banchero [1995] ECR I-4663; Case C-162/97 Criminal proceedings against Nilsson and others [1998] ECR I-7477.

27 Case C-391/92 Commission v Greece [1995] ECR I-1621.

28 Case C-63/94 Belgapom v ITM and Vocarex [1995] ECR I-2467.

29 Bible, Exodus 20:8; Deueronomy 5:12.

30 Wulf-Henning Roth, 'Wettbewerb der Mitgliedstaaten oder Wettbewerb der Hersteller? Plädoyer für eine Neubestimmung des Art. 34 EGV'(1995) 159 Zeitschrift für das gesamte Handels- und Wirtschaftsrecht 78, 87.
} 
ditions and environmental legislation can serve as examples. ${ }^{31}$ Employers must not pay wages below legally defined national minimum wages or contrary to applicable industrial agreements just because the product goes to a low-wage country where such wages would be admissible. Factories must comply with their national environmental legislation: they must not switch off their pollutant filter just because production is intended for export to a country where factories are not required to have such filters.

Although the effect on competitiveness caused by a mismatch in production conditions is more obvious than that of certain selling arrangements, production conditions as a hindrance to intra-European trade have not attracted much attention in connection with the free movement of goods. National environmental protection measures or minimum wages are not challenged as measures having an effect equivalent to export restrictions (art $35 \mathrm{TFEU}$ ), although they weaken competitiveness and in this way harm the chances for the product on foreign markets.

It is settled law that there is no restriction test for measures having an effect equivalent to export restrictions. ${ }^{32}$ It is generally accepted that the country of production is competent to regulate production conditions-at least when it comes to minimum conditions.

\subsection{Overlapping competence for product-related regulation}

As we have noted, the country of production may set production arrangements, and the country of sale the selling arrangements. Competence, however, is not necessarily exclusive if the selling or production arrangement becomes product related. There is concurring competence for product-related arrangements. Countries of sale and of production may set requirements, but they do not accumulate with the effect that the product must comply with both set of rules. It is sufficient if a product is compatible with one set of product-related rules. So the importer can choose between them.

\footnotetext{
31 Roth (n 30) 87.

32 Case 15/79 Groenveld [1979] ECR 3409, para 7; Case 155/80 Oebel [1981] ECR 1993, para 15; Case 286/81 Oosthoek [1982] ECR 4575, para 13; Case 172/82 Fabricants raffineurs d'huile de graissage $v$ Inter-Huiles [1983] ECR 555, para 12; Case 237/82 Jongeneel Kaas [1984] ECR 483, para 22; Case C-412/97 ED [1999] ECR I-3845, para 10; Case C-12/02 Grilli [2003] ECR I- 11585, para 41; Case C-3/91 Exportur [1992] ECR I-5529, para 21; Case C-293/02 Jersey Produce Marketing Organisation [2005] ECR I-9543, para 71; Case C-205/07 Gysbrechts and Santurel Inter [2008] ECR I-9947, para 40; Anthony Arnull and others, Wyatt and Dashwood's European Union Law ( $5^{\text {th }}$ edn Sweet $\&$ Maxwell, London 2006) recital 16-027; Catherine Barnard, The Substantive Law of the EU: The Four Freedoms ( $2^{\text {nd }}$ edn OUP, Oxford 2007) 132; Classen (n 22) § 23, recital 39; Andreas Haratsch, Christian Koenig \& Matthias Pechstein, Europarecht $\left(7^{\text {th }}\right.$ edn Mohr Siebeck, Tübingen 2010) recital 787; Tamara Perišin, Free Movement of Goods and Limits of Regulatory Autonomy in the EU and WTO (TMC Asser Press, The Hague 2008) 26.
} 
The country of sale may therefore regulate trading hours, because they do not relate to products. These rules are exempted from the restriction test as 'certain selling arrangements' under the Keck judgment. However, the situation is different if the selling arrangements of the country of production affect the sale in another country. Dutch law may allow sales packaging that is prohibited as deceptive in Germany. The Dutch producer of a chocolate bar feels a dual regulatory burden, because the producer must design the sales packaging not only in accordance with Dutch law, but he must also comply with the law of the country where the chocolate bar is to be sold. ${ }^{33}$ Thus, accepting both countries as competent for regulating the sales packaging would hinder intra-European trade.

These so-called product-related selling arrangements fall within the scope of the restriction test of the free movement of goods. If the chocolate bar already complies with the rules in force in the country of origin, additional restrictions may only be imposed by the country of sale if this is covered by the written grounds of justification of art $36 \mathrm{TFEU}$ or if it is necessary in order to fulfil the mandatory requirements in the public interest.

The opposite situation does not attract as much attention. The country of production may, of course, regulate production conditions. This competence is non-concurring insofar as the requirements are not product related. Nobody seriously proposes that one may go below minimum wages or switch off pollutant filters just because goods are being produced for export. Product-related requirements for production are only discussed as a possible obstacle for imports. They attract as much attention as non-product-related processes and production methods, especially at the WTO level, when states close their markets for products manufactured under conditions regarded as inadequate at the point of sale. ${ }^{34}$ So, the focus is on restrictions on imports in the international context, whereas production requirements as obstacles for exports need to be discussed here.

Rules such as those about the minimum alcoholic strength of a liqueur can concern sales (liqueur may only be sold if it has a certain alcohol content), as well as production (liqueur may only be produced with a certain alcoholic strength). In the second case, the question arises about whether production must be allowed if the product (eg liqueur) is to be exported to a country whose rules are observed. However, the analogy

\footnotetext{
33 Case C-470/93 Verein gegen Unwesen in Handel und Gewerbe Köln v Mars [1995] ECR I-1923, para 13.

34 GATT Panel Report, United States - Restrictions on Imports of Tuna, DS21/R, DS21/R (3 September 1991) unadopted, BISD 39S/155, para 5.15; Perišin (n 14) 137.
} 
to selling arrangements suggests the opposite: taking the case law seriously, there is no restriction test for measures having an effect equivalent to import restrictions, which means that regulating production belongs to the non-concurring competence of the country of production, even if the regulation is product related.

For the competence approach, the only thing that matters is that there is a distribution of competence. The free movement of goods is only relevant as far as additional rules are concerned. The country of production may only impose more severe rules for production for goods intended for export than for goods that are to stay in the country if this is covered by the written grounds of justification of art 36 TFEU. The country of destination must accept the production conditions in the country of origin, even if they are product related. Additional requirements imposed by the country of sale are admissible if this is justified by the grounds of art 36 TFEU or if they are mandatory requirements in the public interest.

\subsection{The European Union}

The European legislator can simplify the situation just by passing harmonisation measures. So, if you ever plan to sell crème de cassis made in accordance with your sole recipe, it might be a good idea to look first at Regulation (EC) No 110/2008. ${ }^{35}$ You can learn in No 34 of its Appendix II that crème de cassis is a blackcurrant liqueur with a minimum sugar content of 400 grams per litre and a minimum alcoholic strength of $15 \% .{ }^{36}$ Obviously, there is European legislation that would very likely conflict with the free movement of goods if it were enacted at the national level.

How is it possible for the European legislator to fix a minimum level of alcoholic strength for blackcurrant liqueur? What is it about the argumentation of the Court in its Cassis de Dijon judgment that provides that it is not necessary to fix a minimum alcoholic strength for liqueur in order to safeguard the fairness of commercial transaction, because it is a simple matter to ensure that suitable information is conveyed to the purchaser by requiring the display ... of the alcohol content on the packing of products'? ${ }^{37}$

\footnotetext{
35 Council Regulation (EC) No 110/2008 of the European Parliament and of the Council of 15 January 2008 on the definition, description, presentation, labelling and the protection of geographical indications of spirit drinks and repealing Council Regulation (EEC) no 1576/89 [2008] OJ 2008 L39/16.

36 The denomination 'Cassis de Dijon' is, according to Appendix III of Regulation (EC) No $110 / 2008$, reserved for crème de cassis from France.

37 Case 120/78 Rewe v Bundesmonopolverwaltung für Branntwein [1979] ECR 649, para 13.
} 
One could certainly argue that European legislation is not as severely scrutinised as national legislation or that a broader margin of discretion is conceded to the European legislator than to the national legislator. A coherent argument for this correct observation is difficult to find. In the end, the Court found a breach of the principle of proportionality in the quoted passage, a principle to which the European legislator is also committed in accordance with art 5 (4) TEU. So, if intra-European trade must not be hampered by unnecessary national regulation, why should apparently equally unnecessary legislation from a European source be allowed?

If there is harmonisation, it suffices that the product complies with it. So, once again, it is enough that the product complies with one set of rules. The European minimum rule for alcoholic strength is not tested as a second set of rules as was the case with the German legislation in the Cassis de Dijon case. European regulation is the first set of rules, as in the French minimum rule for alcoholic strength in the Cassis de Dijon case. However, a second set of rules must prove that it is necessary to deviate from the general distribution of competence, since it is only a second or additional set of rules that can hamper intra-European trade.

With regard to the free movement of goods, the necessity of the first set of rules is not questioned at all. Today, any liqueur producer must accept the European rule for minimum alcoholic strength, just as REWE (the plaintiff in the Cassis de Dijon case) had to accept the French rules. Neither could REWE have sold Cassis de Dijon with less alcohol than allowed in France at that time, nor may anyone today sell crème de cassis that does not comply with Regulation (EC) No 110/2008. With regard to the free movement of goods, it is wholly irrelevant how much alcohol the first set of rules requires, or if it is necessary to ban under-alcoholised liqueurs from the market.

\section{The individual}

The previous sections have shown that to a significant extent the free movement of goods is primarily about the distribution of competence amongst state authority. One can easily gain the impression that there is no area conceded to the individual's competence. Apparently, the individual cannot decide about what should be in crème de cassis. The market may not export or import or produce whatever it wants. Until now, the free movement of goods only decides who may set the rules. The first set of rules, however, was not tested at all by the yardstick of the free movement of goods in the discussed cases.

The first set of rules, however, might be tested for compliance with superior legal sources. A national rule, for instance, can be unconstituti- 
onal. And so can European law if it conflicts with primary European law. And this is precisely the point where the individual might come into play.

\subsection{Safeguarding the functioning of the market}

One superior source of law is the TFEU with its market freedoms. The first set of rules was not tested on compliance with market freedoms, because there was obviously no infringement. Production, shipping or selling arrangements can, however, hamper intra-European law, and not only if they diverge within the internal market as is the case with a dual regulatory burden.

\subsubsection{Market access as subject of protection}

The above point is especially true where the functioning of the market is concerned. Markets work notably well according to the theory of perfect competition if it is easy to enter and leave a market, if there are consequently many actors on the supply and demand side, if there is perfect information, if the products are homogenous, and if transaction costs are low. ${ }^{38}$ Although it seems at first sight that harmonisation concerns uniformity of supply, market freedoms and legal harmonisation are rather about market access. There may be other tools in European law that take care of the other aspects of a functioning market-a sufficient number of suppliers is, for instance, one task of competition law-but market freedoms are about keeping down the costs of market entry.

\subsubsection{Market transparency ('perfect information')}

Market transparency is discussed as a prerequisite for a functioning market that could be safeguarded by market freedoms. A functioning market requires that the demand side knows what is offered on the market. Commercial communication is therefore essential for a functioning market. For this reason, regulation of advertising belongs to the particular cases of selling arrangements which-unlike most selling arrangements - are actually capable of hindering intra-European trade in accordance with the Dassonville formulation, ${ }^{39}$ just because they render the market less effective.

Nonetheless, the ECJ has steadily decided that even these particular selling arrangements are only tested under the discrimination test. ${ }^{40}$ Although rules limiting market transparency may constitute restrictions to

\footnotetext{
38 Maher Dabbah, EC and UK Competition Law (CUP, Cambridge 2004) 4.

39 Case 8/74 Dassonville [1974] ECR 837, para 5; Case C-292/92 Hünermund and others $v$ Landesapothekerkammer Baden-Württemberg [1993] ECR I-6787, para 21; Case C-34/95 Konsumentombudsmannen v De Agostini and TV-Shop [1997] ECR I-3843, para 43; Commission v Italy (n 9) para 33.

40 Hünermund (n 39) para 21; Case C-110/05 Commission v Italy [2009] ECR I-519 ๆ 28.
} 
market access, they are only governed by the principle that it is enough to stick to one set of rules, in the case of selling arrangements to those in force at the point of sale. These rules must be the same for domestic and imported products. Restrictions of market transparency comply with the free movement of goods if they restrict market entry in the same way for domestic and for imported products. ${ }^{41}$ So, market transparency as such is not a subject of protection for the free movement of goods.

Hence, the nearly total ban of tobacco advertisements by Directive $2003 / 33$ /EC on the approximation of the laws, regulations and administrative provisions of the Member States relating to the advertising and sponsorship of tobacco products ${ }^{42}$ (Tobacco Advertising Directive) complies with the free movement of goods, although it severely limits the chances of market entry for products not already present on a given market. ${ }^{43}$ Since market entry is equally difficult for domestic and foreign newcomers, it is not discriminatory and is thus compatible with the internal market and the free movement of goods. As the Court held for a nearly complete ban of advertising for a certain product at the national level, to wit the restrictive Swedish rules on advertising for alcoholic beverages:

$[\mathrm{P}]$ rovisions restricting or prohibiting certain selling arrangements are not liable to hinder intra-[European] trade, so long as they apply to all relevant traders operating within the national territory and so long as they affect in the same manner, in law and in fact, the marketing of domestic products and of those from other Member States. $^{44}$

\subsubsection{Homogeneity of supply}

The tobacco market is also illustrative of a functioning market in another aspect: the homogeneity of supply. Directive 2001/37/EC on the approximation of the laws, regulations and administrative provisions of the Member States concerning the manufacture, presentation and sale of tobacco products ${ }^{45}$ requires different packaging for every single Member State. Cigarette packets allowed in one Member State must not be

\footnotetext{
${ }^{41}$ Case C-405/98 Gourmet International Products [2001] ECR I-1795, para 15; Commission $v$ Italy $(\mathrm{n}$ 9) para 36.

42 Directive (EC) 2003/33 on the approximation of the laws, regulations and administrative provisions of the Member States relating to the advertising and sponsorship of tobacco products [2003] OJ $2003 \mathrm{~L} 152 / 16$.

43 Case C-380/03 Germany v Parliament and Council [2006] ECR I-11573, para 15.

44 Case C-405/98 Gourmet International Products [2001] ECR I-1795, para 15; Commission $v$ Italy (n 9) para 36.

45 Directive (EC) 2001/37 on the approximation of the laws, regulations and administrative provisions of the Member States concerning the manufacture, presentation and sale of tobacco products [2001] OJ 2001 L 194/26.
} 
sold in another country in accordance with art 5 of Directive 2001/37/ $\mathrm{EC}$, because the health warnings have to be in the relevant combination of official languages of the respective Member State. There is only one exemption: the same packaging can be used for Austria and Germany, ${ }^{46}$ because they are the only two Member States with the same combination of official languages. ${ }^{47}$ If uniformity of supply were a concern of market freedoms, the directive could not legally be based on art 114 TFEU (then art 95 EC, cf first recital to the preamble of Directive 2001/37/EC).

Rules that do not require specific packaging for every single Member State-ie that do not require diverging supply-would be more conducive to the functioning of the internal market. Nonetheless, the ECJ has repeatedly endorsed Directive 2001/37/EC as compatible with the internal market, thus with the free movement of goods (cf art 26 (2) TFEU). ${ }^{48}$ If there were no European legislation, it would be quite obvious that a single Member State-ie France-would have to accept cigarette packets from another Member State (Belgium, Luxembourg) if they bore health warnings in France's official language, even if they were accompanied by health warnings in other languages (German, Dutch, Luxembourgish).

\subsubsection{Summary}

Even where the functioning of a market as such is concerned, as in the case of homogeneity of supply, the free movement of goods confers competence on a specific bearer of authority. There is no question of reserving this for the individual. Market freedoms safeguard market access. They do not concern other aspects of a functioning market, like homogeneity of supply or a sufficient number of suppliers. The regulative core of market freedoms can be boiled down to the right to market access.

\footnotetext{
46 There are even three countries with German as the only official language if you count Liechtenstein where the directive is in force because of the EEA Agreement (Decision of the EEA Joint Committee No 10/2003 [2003] OJ 2003 L94/91).

47 The only languages with official status in more than one Member State are English, French, German, Greek, Swedish and Dutch. English, for instance, is the only official language in the United Kingdom. Irish and Maltese apply in Ireland and Malta. French, Dutch and German are official languages in Belgium, so the language combination differs from the neighbouring countries of France, the Netherlands and Germany, where only one of these languages is official. The linguistic situation in Luxembourg differs from the Belgian one, because Luxembourgish substitutes Dutch as the third official language there. Swedish is the official language in Sweden and Finland, but it shares its status with Finnish only in the former. The same is true of Greek, because Turkish is co-official in Cyprus while Greek is the only official language in Greece.

48 Case C-491/01 British American Tobacco (Investments) and Imperial Tobacco [2002] ECR I-11453, para 193; Case C-434/02 Arnold André [2004] ECR I-11825, para 70; Case C-210/03 Swedish Match [2004] ECR I-11893, para 78.
} 


\subsection{Right to enter a market}

Market freedoms might be equated with the right to market access. This could grant individuals the right to decide where to offer their products. Such a right, however, does not reach far. There might be the freedom to enter a market, but there is no right that there will be a market. Member States may deny drugs, pornography, ${ }^{49}$ lotteries, ${ }^{50}$ and abortion access to the market, although the product may be lawful in another Member State.

Indeed, market freedoms prohibit Member States from restricting existing national markets to national suppliers. Member States must not exclude foreign supply (and also foreign demand) from their national markets. Market freedoms, however, do not require Member States to create a market for a certain product. If Italy does not want motor cycles with trailers on its streets, the free movement of goods does not force it to allow such trailers and to enable foreign trailer producers to sell them to Italian bikers. ${ }^{51}$ If we compare the free movement of goods to the right to vote, for instance, this would be the right to vote without the right to elections.

Although abortion is regarded as a service in the meaning of art 56 TFEU, ${ }^{52}$ the freedom to provide services does not confer the right to anyone to interrupt pregnancies in Ireland. The European legislator may, however, create a market for a certain service in accordance with art 59 (1) TFEU. The European legislator uses art 114 TFEU to open other markets. Directive 2002/24/EC ${ }^{53}$ has, for instance, created a market for light quadric-cycles (art 1 (3) Directive 2002/24/EC), which had not until then been admitted to road traffic in, for instance, Germany.

It is not always simple to say if a certain rule prohibits the market as such or just restricts an existing market for certain products. The rule on the minimum alcohol content of liqueur can serve as an example. If there is no duty to create a market for every product (for instance drugs, lotteries or abortions), why should national legislation not be allowed to close the market for liqueur with little alcohol? What is the difference between the admissible prohibition of trailers for motorcycles and the inadmissible prohibition of liqueur with little alcohol? The decisive difference is not that the former is a prohibition of use, but that the latter prohibits the

\footnotetext{
49 Case 34/79 Henn and Darby [1979] ECR 3795, para 22.

50 Case C-275/92 HM Customs and Excise v Schindler [1994] ECR I-1039, para 62.

51 Commission v Italy (n 9).

52 Case C-159/90 Society for the Protection of Unborn Children Ireland $v$ Grogan and others [1991] I-4685, para 21.

53 Directive (EC) 2002/24 of the European Parliament and of the Council of 18 March 2002 relating to the type-approval of two or three-wheel motor vehicles and repealing Council Directive 92/61/EEC [2002] OJ 2002 L124/1.
} 
sale of a product. The ban of sale is the more severe intervention. Therefore, it could be expected that prohibiting the sale of a product rather than just its use in road traffic would be incompatible with the free movement of goods.

Since market freedoms make no claim for a certain market to be created, but a right to be admitted to a market when there is such a market, the decisive point is whether there is already a market in place. Tools of competition law can help to determine if there is a market and if a certain product belongs to it. We can test if a product belongs to an already existing market by demarking the relevant market. If a product that belongs to a market is not admitted to it, market freedoms can help. If the product does not belong to an already existing market, market freedoms do not require that that market be created. Competition law uses the relevant market concept for delimiting markets. ${ }^{54}$ Two products belong to the same market if they address the same demand, ie if the demand for one product can in principle also be satisfied by the other product.

Cassis de Dijon with an alcoholic strength of $15 \%$ had to be admitted to the German market because this liqueur addressed the same demand as alcoholic beverages already present on that market. In contrast, abortion need not be legalised in Ireland because there is no service present in Ireland that could serve as a substitute for the demand for the medical termination of pregnancy.

\subsection{Market freedoms and European legislation}

The litmus test, however, is whether or not this right to market access, the liberty to enter a market, reserves an area of competence for the individual, even vis-à-vis the European legislator. If there were a fundamental right to market access, any bearer of authority would have to be committed. In the language of the competence approach, market freedoms would not reserve competence for an individual if it was already the exclusive competence of the European legislator. If individuals shared their competence with the European legislator, this would also be compatible with the idea of market freedoms being fundamental rights. This would be the case if the European legislator had to prove the necessity of legislation under the yardstick of proportionality.

There is seemingly little room for doubt that European institutions are bound by market freedoms. The ECJ has repeatedly stressed the

54 Commission Notice on the definition of relevant market for the purposes of Community competition law [1997] OJ 372/5); Haratsch, Koenig and Pechstein (n 34) recital 1094; Classen (n 22) § 21, recital 13; Arnull (n 32) recital 24-004. 
commitment of European institutions to market freedoms. ${ }^{55}$ Doctrine endorses in general this commitment, ${ }^{56}$ but concedes a certain margin of discretion to the European legislator. ${ }^{57}$ This diverging level of commitment is incompatible with the idea of fundamental rights. The problem, however, is the lack of a clear line of argumentation for a reduced level of commitment. If market freedoms are applicable to Member States and the European Union itself, it needs to be explained why both are not committed in the same way.

The Member States are committed to market freedoms because of the supremacy of European law. ${ }^{58}$ When we look at the areas of Union competence, nothing hints at the supremacy of internal market policy over other policies with regard to the European Union itself. Beside transEuropean networks, fisheries and other more or less important fields of Union activity, the internal market appears in a long list of principal areas of shared competence in art 4 (2) TFEU. In contrast, art 7 TFEU stresses the equality of all areas of Union competence.

\subsubsection{The beyond powers approach}

The thesis to be tested is that the European Union is not directly committed to market freedoms, but it cannot infringe on them within its competence. If true, this would show why the commitment of the Member States to market freedoms differs from that of the European Union: their diverging commitments are simply based on different foundations. The European Union is not bound by the codified market freedoms themselves, but it simply cannot infringe on them within its competence.

\subsubsection{The areas of Union competence}

Some competence norms for the European Union serve the idea that if the internal market does not function without the harmonisation of na-

\footnotetext{
55 Case 80/77 Les Commissionnaires Réunis and Les Fils de Henri Ramel [1978] ECR 927, para 35; Case 15/83 Denkavit Nederland [1984] ECR 2171, para 15; Case 37/82 Rewe-Zentrale [1984] ECR 1229, para 18; Case C-51/93 Meyhui v Schott Zwiesel Glaswerke [1994] ECR I-3879, para 11; Case C-114/96 Kieffer and Thill [1997] ECR I-3629, para 27; Case C-434/02 Arnold André [2004] ECR I-11825, para 57; Case C-154/04 Alliance for Natural Health and others [2005] ECR I-6451, para 47.

56 Petersmann (n 1) 1.

57 Heinrich Matthies, 'Die Verfassung des Gemeinsamen Marktes' in Roland Bieber (ed), Das Europa der zweiten Generation (festschrift for Christoph Sasse) (Nomos Verlagsgesellschaft, Baden-Baden 1981) 127; Wulf-Henning Roth, 'The European Economic Community's Law on Services: Harmonization' (1988) 25 CML Rev 35, 76; René Barents, 'The Unity of the Common Market. Some Reflections on the Economic Constitution of the Community' (1990) 33 German Yearbook of International Law 9, 21; Rolf-Oliver Schwemer, Die Bindung des Gemeinschaftsgesetzgebers an die Grundfreiheiten (Peter Lang, Frankfurt/Main 1995) 37 and 209; Torsten Körber, Grundfreiheiten und Privatrecht (Mohr Siebeck Tübingen 2004) 88.

58 Case 6/64 Costa $v$ ENEL [1964] ECR 585; Arnull (n 32) recital 5-008.
} 
tional legal systems, the European Union may facilitate the functioning of the internal market by approximation or through harmonisation measures. Competence norms of this type do not allow infringement on market freedoms. They only empower the promotion of market freedoms. The most prominent competence of this kind is art 114 TFEU, general competence for the approximation of laws in the internal market. ${ }^{59}$ Others are connected to a single market freedom, to wit arts 46, 53, 56 and 59 TFEU. 60

However, the European Union may also pass legislation which is not directly connected to the internal market and market freedoms. There are a lot of other competences. A conflict with market freedoms can occur here, because Union competence is not directly tied to market freedoms, for the competence norms have objectives other than promoting the internal market. The problem can be reduced to the question of whether or not the European Union can act in these non-economic areas of Union competence in conflict with market freedoms.

\subsubsection{Possible competence conflicts}

A conflict between market freedoms and some other policies is hardly imaginable. It seems, for instance, rather difficult to infringe on the free movement of a worker by means of the development co-operation competence of art 209 (1) TFEU. Other competence norms, however, appear more dangerous to market freedoms. Consumer protection, for example, has often been engaged by Member States to justify obstacles to the free movement of goods and other market freedoms. ${ }^{61}$ Another equally dangerous competence is environment protection (art $11 \mathrm{TFEU}$ ) with its competence norm of Article 192 TFEU. If these competence norms allowed measures regulating the internal market, the European legislator could pass legislation in conflict with market freedoms.

The ECJ had the chance to decide in such a conflict on the occasion of the Titanium Dioxide Directive (89/428/EEC). ${ }^{62}$ The Council had issued this directive under the competence of environment protection measures (now art 192 (1) TFEU). The directive prohibited the titanium dioxide industry from introducing its toxic waste into the sea. Its purpose

\footnotetext{
59 Isidora Maletić, 'The Boundaries of the Internal Market after the Lisbon Treaty: A Closer Look at Article 95 EC' (2009) 5 Croatian Yearbook of European Law and Policy 19, 20.

60 Schwemer (n 57) 35.

61 Case 120/78 Rewe-Zentral AG v Bundesmonopolverwaltung für Branntwein [1979] ECR 649, para 9; Case 407/85 Drei Glocken and others $v$ USL Centro-Sud and others [1988] ECR 4233, para 15; Case 178/84 Commission v Germany [1987] ECR 1227, para 14; Case C-470/93 Verein gegen Unwesen in Handel und Gewerbe Köln v Mars [1995] ECR I-1923, para 7.

62 Case C-300/89 Commission v Council [1991] ECR [1991] I-2867.
} 
was to bring to an end competition distortion by ecological dumping within the European titanium dioxide market.

The ECJ decided that the European legislator could not pass this directive on the basis of environment protection competence. According to art 11 TFEU, environment protection must always be observed. Environment protection is therefore one of the most general objectives of the European Union. According to its wording, art 192 (1) TFEU only allows legislation for the realisations of one aim (art 191 TFEU, environment protection), whereas measures taken by the European legislator under, for instance, art 114 TFEU must serve first the internal market objective and second, because of the cross-section clause of art 11 TFEU, the objective of environment protection. ${ }^{63}$ The Community legislator must not adopt a measure on the basis of non-market competence if the effect on the internal market is more than merely incidental. ${ }^{64}$ The legislator is forced to use competence norms made for the fulfilment of the internal market, but these competence norms only allow measures to be adopted that are compatible with market freedoms.

Art 114 TFEU is therefore more specific than art 192 (1) TFEU, because the former requires two objectives to be taken into account, whereas the latter just one. ${ }^{65}$ Accordingly, the more specific one has to be taken due to the principle lex specialis derogat legi generali, ${ }^{66}$ which means that if two regulations at the same level are applicable in the same situation, the more specific one prevails. ${ }^{67}$ If the more general one prevailed, no field of application would remain for the more specific rule, whereas, the other way round, the more general rule will still have its field of application where the specific one is not pertinent.

The ECJ sets out that a measure which affects the internal market as well as environment protection must not be taken using art 192 (1) TFEU if the measure is conducive to the attainment of the internal market and thus falls within the scope of [art 114 TFEU] a provision which is particularly appropriate to the attainment of the internal market. ${ }^{68}$ The Court further clarified its jurisdiction in the waste shipment case: art 114 TFEU must be taken if the internal market is 'affected' by the measure in question. ${ }^{69}$ It is only inapplicable if the effect on the internal market is

63 Case C-300/89 Commission v Council [1991] ECR [1991] I-2867, para 8.

64 Tamara K Hervey, 'Up in Smoke? Community (Anti)-Tobacco Law and Policy' (2001) 26 ELR 101, 120.

65 Commission v Council (n 63) para 8.

66 Haratsch, Koenig and Pechstein (n 32), recital 371.

67 Matthias Pechstein, 'EG-Umweltrechtskompetenzen und nationale Alleingänge beim Umweltschutz' (1996) 18 Juristische Ausbildung 176, 178.

68 Commission $v$ Council (n 63) para 23.

69 Case C-155/91 Commission v Council [1993] ECR, I-939, para 19. 
only 'incidental'. ${ }^{70}$ As a conclusion, article 114 TFEU must be used if the effect on the internal market is more than just incidental. Since art 114 TFEU may only be used for promoting the internal market, the European legislator may only pass legislation with effect on the internal market if this effect is positive. The European legislator lacks the competence to erect hindrances to the internal market. The jurisdiction can be transferred to other policies. In fact, before the waste shipment case, the ECJ had already established the same rule for the relationship between art 114 TFEU and the health protection competence of art 31 (2) EA in its Chernobyl II judgment. ${ }^{71}$

\subsubsection{Implications for European legislation}

According to the beyond powers approach, the European legislator seems to be committed to market freedoms, but in a different way from the Member States. The European legislator is committed to market freedoms because the legislator has competence only for legislation directly regulating the internal market if this legislation is conducive for its attainment. Legislation with only an incidental effect on the internal market can however be passed without observing market freedoms. Nevertheless, the European legislator is bound by the general prohibition of discrimination referred to in art $18 \mathrm{TFEU}$ in such a case.

Although commitment to the market freedoms of the Member States and the European Union differ with regard to their legal basis, the commitment itself is quite alike. European legislation directly affecting the internal market will usually be comparable to what is addressed by the restriction test of the market freedoms. Discriminatory measures are explicitly prohibited by art 18 TFEU. European legislation with only an incidental effect on the internal market serves objectives that would be deemed mandatory requirements if they were invoked by Member States. The principle of proportionality, which must be observed when justifying national measures on grounds of mandatory requirements, must be obeyed by European legislation because of art 5 (4) TEU. The major difference is that national measures must prove that they are necessary, even though they intrude into the area of the protection of market freedom, whereas European measures do not specifically need to prove their necessity with regard to market freedoms.

\footnotetext{
70 Commission v Council (n 69) para 19; referring to the Chernobyl II case: Case 70/88 Parliament $v$ Council [1991] ECR I-4529, para 18.

71 Case 70/88 Parliament $v$ Council [1991] ECR I-4529, para 17.
} 


\section{Conclusion}

The beyond powers approach can explain the commitment of the European institutions to market freedoms without referring to the legal basis that commits the Member States. This causes slight differences in the extent of commitment. While the measures of the Member States can really conflict with the subjective right of an individual granted by market freedoms, a conflict of European measures with market freedoms is rather a question of coherence among the different areas of Union competence. The initial thesis is apparently true: there is no area of competence conceded to the individual. What seems to be the area of protection of a fundamental right to market access is only protected against intrusions by one branch of state authority, to wit the Member States. Although it is difficult for the European institutions to actually break market freedoms, it is due to their own lack of competence rather than because competence here would be reserved for the individual.

The difference for the practical application of European law might be marginal. However, this is only true for the moment. The difference will become highly visible as soon as the European Union acquires competences which do not so easily step back in favour of art 114 TFEU-that is, just because the internal market is affected. 